\title{
The Problem of the Origin and Development of Spiritual Verse as a Genre
}

\author{
Aleksandr Trofimov \\ Department of Choir Conduction \\ Krasnoyarsk State Institute of Arts \\ Krasnoyarsk, Russia \\ E-mail: tav.81@bk.ru
}

\author{
Andrei Sapsuyev \\ Department of Music History \\ Krasnoyarsk State Institute of Arts \\ Krasnoyarsk, Russia \\ E-mail: postprintpack@gmail.com
}

\author{
Svetlana Voitkevich \\ Department of Music History \\ Krasnoyarsk State Institute of Arts \\ Krasnoyarsk, Russia \\ E-mail: art-vice-rector@yandex.ru
}

\begin{abstract}
The article gives consideration to different aspects of the origin and development of spiritual verse genre as one of the earliest samples of traditional song culture. It also depicts such phenomenon as kaliki perekhozhie (travelling singers) in its development and the notion's evolution. The article describes specific influence of performing practice on formation of out-liturgical singing. It explains the historical reasons why the genre almost completely disappeared which has resulted in the loss of living tradition. There is also information about folklore expeditions to different parts of the Krasnoyarsk territory and about the researchers who recorded samples of spiritual verses at the turn of the 20th-21st centuries.
\end{abstract}

Keywords—song folklore; spiritual verse; kalika perekhozhy (travelling singer); ethnographic expeditions; Krasnoyarsk territory

\section{INTRODUCTION}

Singing is one of the earliest ways of a person's selfexpression. That is why it has taken roots in the traditional culture of all the ethnic groups living on our planet. A song is born, lives and grows together with any nation accompanying the people throughout their lives. It reflects the nation's history, everyday life, manners, habits and ways, as well as the depths of the nation's spirit and outlook. Traditional singing is primarily a kind of artistic communication within a family, a clan, a village, a town or city that is expressed in different forms: it is communication during the work reflected in the calendarian and ceremonial folklore; it is the ritual form of family relations within a family (a clan, a community) in their everyday rites (wedding, burial, funeral feast); and it is the highest level of the nation's social adaptation reflected in its historical and heroic epics. In other words, singing is a nation's nonmaterial heritage. Alongside with a civilization's development, the role of song folklore switched from the practical sphere to the area of aesthetic needs; artists were also required who could satisfy the needs. First, the song was a part of everyday speech but gradually it started "to be created as a kind of artistic thinking, just like complicated philosophic treatises and deep poetic and prosaic works are composed from the elements of living everyday speech" [1]. The ability "to play" a song skillfully had always been highly estimated by the people. People used to express their gratitude, love and admiration in different ways: they could discharge singers from hard work, give them a place of honour in a house, a gift or something especially delicious. The singers' skills used to satisfy the people's needs carrying them away to the world of fantastic images and elevated feelings. "The living sensitive environment surrounded the keepers of the song heritage to make favourable atmosphere for composing and performing songs" [2].

\section{GENRES OF RUSSIAN SONG FOLKLORE}

Russian traditional song folklore possesses a broad variety of genres. The earliest of them is connected with agriculture and reflected in the farmers' calendarian songs; another one is made of work songs and shanties. One more genre comprises lamentations and conclamations; as Borislava B. Yefimenkova observes, "in many respects it is the key to understanding the genesis and aesthetics of the Russian traditional song art" [3]. Folk singing is essentially syncretic and expresses not only with a voice but also with movements. That is why it is impossible to fully bring round and dance songs to the listeners without knowing the functional and cultural integrity of these song genres, without the ability to dance. One of the most expressive genres which has preserved the unique image of the Russian

Traditional folk songs, round dances or games always imply a theatrical acting accompanied with mimics, gestures or dances. A singer used to live through a song as an actor playing on stage. In the Don River region, they still say "to play a song" instead of "to sing a song", i.e. to live another person's life instead of the singer's own. 
people and their generous souls is the long song. It has revealed the main thing in music - personal feelings. Born among farmers in about 16th-17th centuries, it had reached the top of song skill by the 19th century; the genre has been the national foundation of the works composed by both amateurs and professionals. Finally, the "deepest" genre that has preserved the people's historical memory and the basics of their spirituality and outlook is the Russian epic. It includes bylinas [Russian traditional epic ballads], ballads, historical songs and spiritual verses. While the long and lyrical songs are aimed at reflecting a person's inner world and are sung "to oneself", the epics are addressed to all the people (community). That is why epics presuppose interaction of the singer (narrator) and the listeners (the audience). Another characteristic feature of the genre is using musical instruments to accompany the vocal part. As a rule, gusli [Russian traditional multi-string plucked instrument] of different types (wing-shaped, psaltery etc.) was used for performing bylinas, while the typical instrument for spiritual verses was hurdy-gurdy. People often learn about bylinas, about their heroes and boyans [kind of bards who used to perform the music] in their childhood, they read books and have at least a minimum perception about them. However, most people know practically nothing about spiritual verse and kaliki perekhozhie (travelling singers) carrying hurdy-gurdies in their hands. That is why we would like to touch upon the origin and development of the spiritual verse as a genre, and to mention the people who had been studying the genre for years. The practical material for the article is the recordings made in different time by various ethnographic expeditions to the regions of the Krasnoyarsk territory.

\section{THE SPIRITUAL VERSE. ITS AUTHORS AND PERFORMERS}

The first samples of spiritual verse originated in Ancient Rus after adopting Orthodox Christianity. Much of the genre's works had been known by the 15 th century. Contemporarily, they are musical and poetic artifacts connected with Christian subjects and imagery and representing a certain form of self-expression through understanding of the Orthodox outlook. Stylistically, spiritual verses are varied: this can be seen in the intertwining of Christian and archaic elements, in the mixture of the Russian and Church Slavonic languages as well as in the fact that they were formed and existed in two traditions, both written and oral. Generally, people used to apply the term "verse" to out-liturgical spiritual songs and hymns and emphasized the fact that they were not the "songs" born in the secular environment, but another type of art. Their contents are not connected with everyday problems; they are used to express supreme spiritual values determined by sacral events (burial and remembrance rites, fasting, church holidays, etc.) The people say, "to play a song and to sing a verse". According to people's views, there are angel, cherub, seraph verses, i.e. people put them into the mouths of Supreme Forces, as P. A. Bezsonov writes $[4]^{2}$. Spiritual

The researcher also says that the word "verse" comes back to the culture of Ancient Greece and Byzantium and it reflects the early concepts verses [or stichera] were widespread thanks to groups of kaliki perekhozhie (travelling singers). That is why the "Explanatory Dictionary" by Vladimir Dahl gives the word stichernik (stichirnik) the following definition: "a northern word for a beggar or an old man who knows lots of folk verses (stichera) or dumas [thoughtful songs]" [5]. However, it was originally the name for pilgrims who used to go on mass pilgrimages to Jerusalem, Tsarigrad (Constantinople) and other "holy places". The name of "kaliki" [plural form; singular is kalika - Translator's note] comes from a special kind of sandals, caligae ${ }^{3}$, worn by the pilgrims. Almost all well-known Russian pilgrims were the first kaliki: Daniil the Hegumen (about 1118); Grigory Kaleka (about 1321-1323), the future Novgorod archbishop; the monk Stefan Novgorodets (about 1350), born a rich Novgorod boyar [a representative of Russian nobility], and others. They left "Travels" behind them, handwritten travel notes. We can draw a conclusion that the pilgrims used to travel with their squads, they also hired guides and had enough money to pay for prayers and burial services. The kaliki themselves used to be quite well off because a journey to Palestine was rather expensive at that time. The children of boyars or merchants (of different ages and wealth) often became kaliki. In Russian bylinas, kaliki are not depicted as poor and miserable blind people; otherwise, they are strong men. Even when they were shown as old men, they were not those to evoke any sympathy because of body injuries [the word "kalika" sounds similar to "kaleka", a disabled person Translator's note]. According to the well-known Russian philologist, Slavist and ethnographer, Izmail Ivanovich Sreznevsky, “... in the bylinas, kaliki almost always combine their body force with their spiritual power. They are like wizards whose muscle power expresses the force of their spirit. The magic power seems to be hidden in their very looks, in everything which makes them kaliki outside" [6]. The kaliki used to start their pilgrimages from monasteries. For example, bylinas mention the Yefimieva hermitage and the Bogolyubovskaya monastery. After coming back from Holy places many kaliki used to take monastic vows and travel around Russia telling about their adventures and often writing them down:

"Kaliki the wanderers used to come,

They cross themselves as they write it to be done,

They bow in a learned way",

the bylina about Ilya Muromets renders [7].

In the course of time, the genres popularity with the pilgrims (bylinas, stichera and travels) had become the domain of professional begging singers who were mostly blind. They started to compose their own religious verses besides written texts. The further lives of such singers were connected with the church ${ }^{4}$. They mostly lived next to

of Orthodox Christianity. The Byzantine service book, Sticherarion, which was widespread in Ancient Rus, included stichera [verses, hymns] and outliturgical texts.

3 Lat. caligae, boots.

"Out of numerous Russian pilgrims to Holy Land, after their pilgrimages, the wealthy ones remained as they used to be; the poor ones 
churches and monasteries where their main activity was begging at the church porches and next to monastery gates. In accordance with that, the word "kalika" (coming from the pilgrims' footwear) was gradually changed for "kaleka" meaning people with physical deformities. And in the singers' new environments, the word acquired the new meaning, as "the travelling kaleka [cripple]". The blind musicians used to earn their living in marketplaces and fairs singing eagerly because they wanted to get something for their work, either some money or another kind of alms. "In Little Russia [the name of Ukraine in tsarist times] one can always hear the hurdy-gurdy players' mournful voices among the varied hustle and bustle of the fairs, they sit on the ground, full of dignity, amidst the fussy crowds that do not mind listening to a plain tune accompanied from time to time with wailsome sounds of a hurdy-gurdy; people reward the players with generous alms" [9]. Occasionally in the winter, kaliki used to visit someone's home, and it had always been an honour to host a singing blind man. Thanks to kaliki perekhozhie the spiritual verses became widespread all over the territories inhabited by Slavonic people. For example, the Serbian analogue of the Russian spiritual verses is побожне пјесме / pobozhne pesme (pious songs), the Czech spiritual songs can be found in Zpevniks, or song collections; the Poles call them piesni religijne (religious songs), while the Bulgarians have божий / bozhi or молебни песни / molebni pesni (God's or prayer songs). Performance practice has significantly influenced the development of the spiritual verse as a genre. Originally, the Russian spiritual verses used to be performed a cappella or accompanied by gusli, but, by the late 16th century, they could have been heard everywhere to the accompaniment of hurdy-gurdy. By the 19th century, the instrument had become quite popular all over the south-western borderlands, especially in Little Russia [Ukraine]. A vivid description of the performing manner is given by N. Privalov in his work of January 21, 1905 , published in a collection of articles under the title of "Proceedings of the Russian and Slavonic archeology department of the Russian Emperor archeological society": "There is a great difference between the kobza players (bandurists) [kobza and bandura are Ukranian folk pluck string instruments of the lute family] and those playing the hurdy-gurdy, both in their instruments and their singing manners as well as in their repertoire. The construction of the bandura or kobza resembles that of the guitar, harp or gusli: it sounds quietly and melodiously. The sounds of the hurdygurdy are sharper and shriller, that is why the musician has to strain the voice for the listeners to understand the words. Because of that, the hurdy-gurdy players' singing is gruffer than that of kobza players and has less musical influence on the crowd. Meanwhile Marchenko's playing was rather pleasant, though he was gloomy, sullen, slow and non-

were in care of the church, as can be seen in bylinas and some copies of Vladimir's Law where the pilgrim and the wanderer were equally included into the number of church people. Having made a pilgrimage to holy places, the poor kaliki were highly respected and remained travelling beggars for life, which was their way to make a living. Thus, the word "kaliki" or "kaleka" got the meaning of a begging traveler. Physically impaired people also used to earn their living in the name of Christ, so the word got its new meaning of a badly injured person" [8]. musical by nature. I heard him play in 1902, at a handicrafts exhibition in St Petersburg, standing next to the composer N. A. Rimsky-Korsakov who was evidently interested in Marchenko's performance and was even making some notes. A common technique of Marchenko's playing was as follows: the blind man used to start a song stanza, then he used to stop singing and play the ritornelle on his hurdygurdy. Thus singing and playing were interchanging. The sound of the instrument was tender though a certain swish of the wheel against the strings could be heard, but never more than that of modern gramophones that might soon be a sign of good style to have at homes all over Russia!" [9].

\section{RESEARCHING THE GENRE. THE SPIRITUAL VERSE IN SIBERIA}

Collecting and researching the spiritual verse became popular in Russia in the mid-19th century (P. V. Kireyevsky, V. Varentsov, P. A. Bezsonov). But in 1918, a period of scholastic oblivion started; it was connected with coming of the Communist power which had its own specific view of traditional culture and the genres of song folklore. Only since the late 1980s, the ethnographers' interest in the spiritual verse has been revived, including the territory of Siberia. The materials of out-liturgical singing were discovered and recorded during field expeditions about the Krasnoyarsk territory, from 1990 to 2012. One of the first researchers was Vladimir Mikhailovich Loginovsky ${ }^{5}$ who explored the Abansk district of the Krasnoyarsk territory in the autumn of 1990. As the folklorist wrote, "in the next years I frequented different villages of the district. I visited some of them twice or three times and recorded not only single performers but also some singing groups" [10]. In the village of Pochet he recorded two spiritual verses (Psalms) from Khristina Fominichna Melnikova, born 1906: "Save Me, My Lord" and "Christ Was Sitting with His Disciples". Another significant find was discovered by Igor Nikolayevich Gorev ${ }^{6}$ during the 2000 expedition in the village of Orlovka, Birilyussky district, Krasnoyarsk territory. The sample recorded by him is unique because it was performed by a group of three.

It is a memorial spiritual verse "Upon a Mountain". In November 2012, the researchers managed to record three spiritual verses and the rite of worshipping the icon of Mikhailo the Archangel, in the village of Ishimka, Bolsheuluisky district, Krasnoyarsk territory.

\section{CONCLUSION}

We regret to say that the people's tradition of the spiritual verse is disappearing without a trace in everyday environment. The genre is rapidly fading away, and the likelihood of it becoming a lost art is increasing. That is why the main objectives of the specialists (ethnographers, philologists, musicians) are searching for new methods of work with the materials collected; dealing with problems of

\footnotetext{
5 Head choir master of the State folk art centre of the Krasnoyarsk territory, head of the "Krasnoyarye" folk ensemble.

A teacher of P. I. Ivanov-Radkevich Krasnoyarsk college of arts, head of the "Zhivaya Starina" [Living Old Times] folk ensemble.
} 
keeping and accessibility; organizing multi-functional folklore archives and laboratories; publishing academic collections and music sheets; and organizing conferences, lectures and concerts promoting the spiritual heritage of Russia.

\section{REFERENCES}

[1] B. V. Asafiev, Music of the Town and Countryside // On Folk Music. - Lenongrad: Muzyka, 1987, p. 109.

[2] L. V. Shamina, Basics of People's Vocal Pedagogics: Textbook - 2nd ed. - SPb: Lan'; The Planet of Music, 2017, p. 13.

[3] B. B. Yefimenkova, North Russian Lamentation. - M.: Sovetsky kompozitor, 1980, p. 3.

[4] P. A. Bezsonov, Russian People and Their Creative Word. - M.; Institute of Russian civilization, 2010, p. 79.

[5] V. I. Dahl, Sticheron // Explanatory Dictionary of Living Great Russian Language: in 4 vol. - M., 2007. V. 4 - M.: OLMA Media grupp, 2007. - $576 \mathrm{p}$.

[6] I. I. Sreznevsky, Russian Kaliki of Ancient Times // Proceedings of the Emperor Academy of Sciences: in 75 vol. - SPb, 1862 - 1985. V. 1, iss. 2 - SPb: Emperor Academy of Sciences Printing House, 1862, p. 198.

[7] N. Vodovozov, Ilya and Svyatogor // Bylinas about Ilya Muromets. M.: OGIZ, 1947, p. 4.

[8] F. A. Brockhaus, I. A. Efron Kaliki or Kaleki Perekhozhie // Encyclopaedical Dictionary: in 86 vol. - SPb, 1890-1907. V. 14 - SPb: Semenovskaya Typolithography, 1895, pp. 27-28.

[9] N. I. Privalov, Lira [Hurdy-Gurdy]. Russian Folk Musical Instrument // Proceedings of the Russian and Slavonic Archeology Department of the Russian Emperor Archeological Society: in 13 vol. - SPb, 1861-1918. V. 7, iss. 2 - SPb: M. A. Aleksandrov's Printing House, 1907, pp. 35-37.

[10] V. M. Loginovsky, Folk Songs of the Abansk District of the Krasnoyarsk Territory // Printed Music. - Krasnoyarsk: Kansk Interdistrict Printing House, 1993, p. 3. 